\title{
Guardian ad litem, a potentially expensive invitation to either the mismanagement or management of patients with cognitive disorders
}

This article was published in the following Dove Press journal:

Clinical Interventions in Aging

29 November 2010

Number of times this article has been viewed

\author{
Richard F Edlich \\ Biomedical Engineering and \\ Emergency Medicine, University \\ of Virginia Health System, \\ Charlottesville, VA, USA
}

Correspondence: Richard F Edlich Biomedical Engineering and Emergency Medicine, University of Virginia Health System, Charlottesville, VA 22908, USA Tel + I 360944764 I

Fax +I 3609447612

Email richardedlich@gmail.com
Abstract: The children of a multiple sclerosis (MS) patient filed a guardian ad litem case to be brought against the patient. The basis for the petition was that the MS patient had a significant reduction is his mental competence. The children were not aware that hyperthermia could adversely affect the brain of MS patients. The patient's urologist recommended he have a suprapubic cystostomy done in a hospital. Passage of the two channel Foley catheter into his bladder immediately resolved his urinary tract infection, fever, and difficulty in communicating. Despite this dramatic improvement in his health from the urologic treatment, he was now faced with resolving his children's petition for a guardian ad litem that would allow them to control his estate including his residence and financial retirement assets. A judge supported this petition by requesting that the patient with MS pay for his children's attorney fees, 24 hour nursing home services that duplicated his own hired personal care assistants, the salary of the guardian ad litem, the attorney fees for the guardian ad litem, and payment for a psychological evaluation. The state law should be changed to require that the petitioner have adequate income to pay for his/her attorney as well as the salary of the guardian ad litem to prevent mismanagement of patients with cognitive disorders. In addition, the guardian ad litem should be an attorney or a registered nurse. The care of disabled individuals subjected to litigation should be coordinated by an attorney or registered nurse.

Keywords: multiple sclerosis, infection control, law, nurse

Guardians ad litem (GALs) are often appointed in divorce cases or in parenting time disputes to represent the interests of the minor children. GALs are also used in other family matters involving grandparents obtaining custody or grandparenting time as well as protection orders where one parent is attempting to get an order against another party with a legal connection to the mother of the child. The kinds of people appointed as a GAL vary by state, ranging from volunteers to social workers to regular attorneys to others with the appropriate qualifications. The two divorcing parents are usually responsible for paying the fees of the GAL, even though the GAL is not responsible to them at all. In some states, the county government pays the fee of that attorney. The GAL's only job is to represent the minor children's best interests. The GAL can be appointed by the court to represent the interests of mentally ill or disabled persons.

The Code of Virginia requires that the court appoint a "discreet and competent attorney-at-law" or "some other discreet and proper person" to serve as GAL to protect the interests of a person under a disability. ${ }^{1}$ (Va. Code $\S 8.01-9$ [Cum Supp 1998]. Va. Code $\S$ 16.1-268.) Virginia Code $\S$ 8.01-9 states that "every GAL shall faithfully represent the estate of the person under a disability for whom he is appointed, and it shall 
be the duty of the court to see that the interest of such defendant is so represented and protected". The court may enforce this duty by removing the GAL and appointing another one.

In this case report, it is important to point out that this GAL was not either an attorney or a registered nurse. His certification as a GAL was achieved by taking courses and becoming certified by an examination. The patient had the diagnosis of multiple sclerosis (MS). This diagnosis was made by the results of an MRI as well as examination of his spinal cord fluid. His spinal cord fluid showed the presence of oligoclonal bands, an indicator of increased immune activity in the spinal fluid. ${ }^{2}$ The MRI of his brain documented the presence of demyelination, primarily in his frontal lobe. ${ }^{3}$ During the next 20 years, he had several documented relapses in his neurologic condition. His condition progressed from ability to ambulate to being confined to a Permobile Chairman 2k Tilt-and-Recline wheelchair. ${ }^{4} \mathrm{He}$ also has used an external condom catheter to collect urine throughout the day.

His illness has not interfered with his contributions to medicine. He has been able to maintain his license in medicine, and provide consultation services to hospitals that have improved patient care as documented by his peer-reviewed publications. The source of information in this report was the patient's primary care physician, who is a specialist in internal medicine, as well as the patient's attorney who represented him in court.

\section{Case report}

When a 72-year-old white male with MS heard the doorbell ring he manually opened the door. A visitor entered the residence and introduced himself as a GAL who is a paid state employee appointed by a judge. The MS patient responded that he would not have time to talk to the GAL because he had been scheduled at a Daycare Surgery Center for a suprapubic cystostomy. Realizing that there would not be adequate time to talk, the GAL left an envelope filled with papers that could be read by the individual after his appointment. The GAL said that he would return to meet with the MS patient after he returned from the hospital following surgery.

Because the patient had been developing excessive urine in his bladder that became infected with Pseudomonas aeruginosa, his urologist prescribed ciprofloxacin $(500 \mathrm{mg}$ PO BID), which did not eliminate his fever of $102^{\circ} \mathrm{F}^{5}$ Suprapubic cystostomy is very popular because it is an easier technique for people with MS who have limited mobility as well as patients with spinal cord injuries. Suprapubic cystostomy creates a tunnel from the abdominal wall of the bladder. A catheter is then inserted into the bladder through the tunnel. The catheter drains into a sterile collection bag and is irrigated daily with sterile saline.

According to Torres-Salazar and Ricardez-Espinosa, it is ideal to change the catheter every two weeks. ${ }^{6}$ The authors also advise that patients with a permanent suprapubic cystostomy have the catheter changed before cultures are taken to reduce the amount of antimicrobials prescribed, and lessen the increase in microbial resistance.

After placement of the suprapubic cystostomy, the patient became afebrile and was allowed to return to his residence without further treatment. Because he was now afebrile, personal care could be easily provided to him by certified nursing assistants that were familiar with the Guldmann ceiling lifts located adjacent from the patient's bed, as well as in the bathroom. Using these modern lift systems, he was able to be transferred by his certified nursing assistants who also wear back braces to reduce the chance for potential injury to their backs. ${ }^{7}$ On his scheduled meeting with the GAL, the GAL informed the patient that there was a meeting with the judge about the guardian ad litem case. A petition had been given to the MS patient by the GAL, in which his two children wanted to monitor and take control of his investment and real estate assets. The GAL advised the MS patient that his own attorney should be in the courthouse. The GAL indicated that he should select an attorney that focuses primarily on litigation on GAL cases.

Since 1890 , the adverse effects of hyperthermia in patients with MS have been recognized. ${ }^{8}$ While most patients with MS experience reversible worsening of their neurologic deficits, several individuals experience irreversible neurologic deficits. In fact, hyperthermia can be caused through sun exposure, exercise, and infection especially a urinary tract infection.

The patient with MS selected a skilled attorney who specializes only in GAL cases, and was willing to represent the individual at the hearing and until settlement of the litigation. The patient, now with a suprapubic cystostomy, was transported by a handicap accessible van to the courthouse for the hearing. The judge made it very clear to the patient that he was responsible for paying his attorney fees, the salary of the GAL, the attorney for the GAL, and the attorney fees for his two children. In addition, he would need an evaluation by a psychologist selected by the GAL. The psychologist met with the MS patient and found normal communication skills, unless the consultation room had an elevated temperature. Finally, the judge indicated that he should receive personal care assistance 24 hours a day by a nursing home service selected by the GAL. The patient seated in the wheelchair 
explained that he did not need nursing provided people care in his home 24 hours a day because he had trained certified nursing assistants working between 7:00 am and 7:00 pm in his residence. In addition, he had an emergency medical alarm system from ADT home monitoring in his residence that was connected to either a wristband or a necklace with a medical alert button that could be pressed to alert emergency medical technicians in an ambulance service to take him to the hospital to treat his life-threatening illness. This system also responds to the presence of smoke or intruders of the home. After the nursing assistant would leave at 7 $\mathrm{pm}$, he was able to contact the individual's cell phone and request any further assistance. In the past, he had never needed the nursing assistant to return for personal care. The judge ignored this suggestion and encouraged the GAL to request that the new nursing home service start providing care 24 hours a day. After the judge made this decision, the MS patient now had two personal care assistants working in his residence.

The individual with MS was now cared for from 7:00 pm until 7:00 am by relatively untrained licensed personal care assistants. When he found that the new nursing home services had no protective back braces and had never transferred a patient from a wheelchair using an overhead ceiling lift, he realized that he could be dropped inadvertently from the ceiling lift. During the three months of his experience with the appointed nursing home services, he had two challenges with hyperthermia induced by the nursing home services staff in his residence. In one case, the nursing home service closed his bedroom door causing a dramatic increase in the temperature in his bedroom. When he developed life-threatening hyperthermia, he had to call on the telephone one of his own hired nursing assistants to come to his home to reduce his body temperature. She opened the door of the bedroom and then removed the patient's pajamas that were soaked with sweat. She than had to wipe his body with cool water, dry his body, and put new dry clothing back onto the patient.

In the next episode, the employee from the nursing home service inadvertently turned off the switch in the bedroom that activated the overhead ceiling fan. When the patient with MS called out for her help, he surprisingly learned that she had a hearing deficit and could not hear his request to turn on the electricity to the overhead fan so he could control it with his remote. Because he now could not use his remote control unit for the fan, he had to call his same hired nursing assistant to return to his home to take care of his elevated body temperature.
Because the hired nursing assistant came to the patient's home to treat him for hyperthermia without contacting the nursing home service, the nursing home service requested that Adult Protective Services file a misconduct or criminal charge against his employee. The attorney for Adult Protective Service's refused to read the scientific publication listed as reference number eight. The attorney expressed no interest in the dangers of hyperthermia in patients with MS and was only interested in processing the litigation case against the employee who saved the patient's life.

The patient's attorney requested that he contact another attorney who specializes in financial settlements. This attorney developed settlement agreements with the GAL and his attorney, the children's attorney, and the nursing home services. The amount of the final bill for the GAL case was US\$62,412.52 (Table 1). The attorney for the patient gave the list of the expenses that were approved and signed by the Judge in written documents. It is important to point out that the two petitioners were not asked to reimburse payment for the GAL or the GAL's attorney.

\section{Discussion}

In this case, the judge made a premature decision in appointing the GAL without initially requesting the patient's medical report so that the judge could understand the medical facts and circumstances that led the patient to manage her physical needs through hired certified nursing assistants. After exploring these facts, the judge could have made her determination of mental competency based on a report from a licensed psychiatrist who spoke with the patient. The fact that the patient with MS was able to make his own decision regarding his physical needs implied that he had mental competency. Although the patient had significant physical disability, he had managed to arrange for surgery by the urologist.

This case has implications for elder abuse, both physical and financial, medical neglect, and the inadequate nursing care rendered in the individual's residence. The physical abuse can be explained by the judge's replacement of the

\section{Table I Expenses}

\begin{tabular}{ll}
\hline Personal attorney & $\$ 15,423.60$ \\
Guardian ad litem & $\$ 3,212.65$ \\
Guardian ad litem attorney & $\$ 15,778.77$ \\
Attorney for children & $\$ 7,500.00$ \\
Psychologist & $\$ 1,797.50$ \\
Nursing services & $\$ 17,500.00$ \\
Settlement attorney & $\$ 1,200.00$ \\
\hline
\end{tabular}


patient's hired personal care assistants with a 24-hour nursing home service that eventually endangered the patient's life by exposing him to hyperthermia, which had to be resolved by one of the patient's hired nursing assistants. The financial abuse can be explained by the judge's order asking the patient to pay all of the expenses that occurred during the litigation. The medical neglect can be attributed to the lack of medical information provided to all parties involved, particularly the children who brought the petition against the father.

The legal system for GAL should have two important changes. The petitioners for a GAL case should have some monetary responsibility. Ideally, the petitioners should be able to pay for the expenses of their own attorney as well as the salary for the GAL. If the petitioners have this financial responsibility, it would ensure that he/she reviews the case carefully before making a decision to file a petition. Secondly, the GAL should be an attorney or a registered nurse who takes training and becomes certified as a GAL.

\section{Disclosure}

The author reports no conflict of interest in this work.

\section{References}

1. Committee Opinion. Conflict; appearance of impropriety; representing Dept. of Social Services and acting as guardian ad litem for other client with matter adverse to Dept. of Social Services. 1999. Available from: http://www.vsb.org/profguides/FAQ_leos/LEO1725.html. Accessed Nov 42010.

2. Gajofatto A, Monaco S, Fiorini M, et al. Assessment of outcome predictors in first-episode acute myelitis: a retrospective study of 53 cases. Arch Neurol. 2010;67(6):724-730.

3. Meier DS, Balashov KE, Healy B, Weiner HL, Guttmann CR. Seasonal prevalence of MS disease activity. Neurology. 2010;75(9):799-806.

4. Edlich RF, Nelson KP, Foley ML, Buschbacher RM, Long WB, Ma EK. Technological advances in powered wheelchairs. J Long Term Eff Med Implants. 2004;14(2):107-130.

5. Edlich RF, Mason SS, Dahlstrom JJ, Swainston BA, Long III WB, Gubler KD, Giesy JD. Residual urinary volume and urinary tract infection, a life threatening illness. J Environ Pathol Toxicol Oncol. 2010. In Press.

6. Torres-Salazar JJ, Ricardez-Espinosa AA. Suprapubic cystostomy indications for and against its implementation. Rev Mex Urol. 2008;683: 170-173.

7. Edlich RF, Hudson MA, Buschbacher RM, et al. Devastating injuries in healthcare workers: description of the crisis and legislative solution to the epidemic of back injury from patient lifting. J Long Term Eff Med Implants. 2005;15(2):225-241.

8. Edlich RF, Buschbacher RM, Cox MJ, Long WB, Winters KL, Becker DG. Strategies to reduce hyperthermia in ambulatory multiple sclerosis patients. J Long Term Eff Med Implants. 2004;14(6): 467-479.
Clinical Interventions in Aging

\section{Publish your work in this journal}

Clinical Interventions in Aging is an international, peer-reviewed journal focusing on evidence-based reports on the value or lack thereof of treatments intended to prevent or delay the onset of maladaptive correlates of aging in human beings. This journal is indexed on PubMed Central, MedLine, the American Chemical Society's 'Chemical

\section{Dovepress}

Abstracts Service' (CAS), Scopus and the Elsevier Bibliographic databases. The manuscript management system is completely online and includes a very quick and fair peer-review system, which is all easy to use. Visit http://www.dovepress.com/testimonials.php to read real quotes from published authors. 